
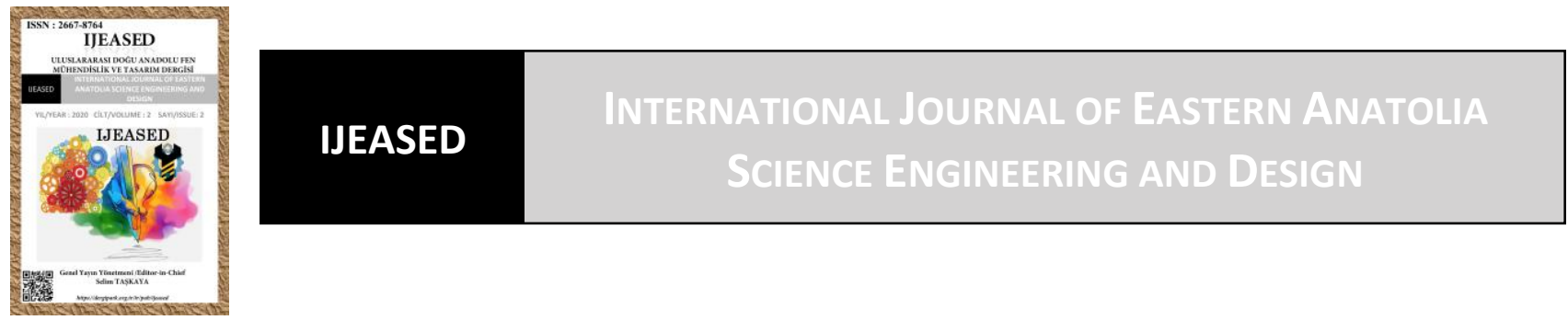

\author{
Uluslararası Doğu Anadolu Fen Mühendislik ve Tasarım Dergisi \\ ISSN: 2667-8764, 2(2), 380-400, 2020 \\ https://dergipark.org.tr/tr/pub/ijeased
}

Araştırma Makalesi / Research Article

Doi: $10.47898 /$ ijeased.756010

\title{
Ön ve Arka Manşon Çapı Farklııklarının Karde Ring İplik Kalite Parametreleri Üzerine Etkisi
}

\author{
Ahmet ZEYBEK *
}

Süleyman Demirel Üniversitesi, Tekstil Mühendisliği ABD, Isparta, 32400, Türkiye.

\begin{tabular}{l|lc|c}
\hline \multicolumn{1}{c|}{ Yazar Kimliği / Author ID (ORCID Number) } & \multicolumn{1}{|c}{ Makale Süreci / Article Process } \\
\hline *Sorumlu Yazar / Corresponding author : & Geliş Tarihi / Received Date $:$ & 21.06 .2020 \\
zeybekahmet@gmail.com & Revizyon Tarihi / Revision Date : & 19.10 .2020 \\
iD https://orcid.org/0000-0001-6248-458X, A. Zeybek & Kabul Tarihi / Accepted Date : & 29.11 .2020 \\
\hline & Yayım Tarihi / Published Date : & 15.12 .2020 \\
\hline
\end{tabular}

Alıntı / Cite : Zeybek, A. (2020). Ön ve Arka Manşon Çapı Farklılıklarının Karde Ring İplik Kalite Parametreleri Üzerine Etkisi, Uluslararası Doğu Anadolu Fen Mühendislik ve Tasarım Dergisi, 2(2), 380-400.

Özet

Ring iplik eğirme sisteminde, ön ve arka manşonun sahip olduğu çap kombinasyonlarının karde ring iplik kalitesi üzerindeki etkisini araştırmak ve daha kaliteli iplik üretmek için hangi çap kombinasyonların daha iyi olduğunu belirlemek amacıyla yapılan bu çalışmada, Ege yöresine ait \%100 pamuk elyafından, kalın ve ince numaralara karşılık olarak Ne 20/1 ve $\mathrm{Ne}$ 40/1 numaraya sahip karde ring iplik numuneleri üretilmiştir. Yapılan çalışma kapsamında, alandaki benzer çalışmalardan farklı olarak, ön ve arka manşon birlikte ele alınmış olup, ring iplik eğirme makinasında, $28 \mathrm{~mm}$ ve $30 \mathrm{~mm}$ ön ve arka manşon çapı kombinasyonları kullanılarak üretilen karde ipliklerin, CVm (\%), İnce Yer ($\% 40 / \mathrm{km})$ ve Kalın Yer $(+\% 35 / \mathrm{km})$ değerleri arasında istatistiki açıdan anlamlı bir fark bulunmuştur. Bu ipliklerin manşon çap kombinasyonlarına göre Neps $(+\% 200 / \mathrm{km})$ değerlerinde ise istatistiki açıdan anlamlı bir farka rastlanamamıştır. Ayrıca, ön manşon çapının büyük olduğu durumlarda arka manşon çapının büyüklüğüne bakılmaksızın iplik kalitesinde artış gözlemlenmiştir. Elde edilen bulgular, ring iplikçiliği işletmelerinde iplik kalitesini artırmaya 1şık tutacaktır.

Anahtar Kelimeler: Ring İplik Eğirme Makinası, Pamuk, Manşon Çapı, İplik Kalite Parametreleri.

\section{Effect of Differences in Front and Back Cots Diameter on Carded Ring Yarn Quality Parameters}

\section{Abstract}

This study aims to investigate the effect of the diameter combinations of front and back cots on the quality of carded ring yarn in the ring spinning system and to determine which diameter combinations are better to produce better 
quality yarn. In this respect, carded ring yarn samples with the number Ne 20/1 and Ne 40/1 were produced from 100\% cotton fiber belonging to the Aegean region. Within the scope of the study, different from similar studies in the field, the front and rear cots were handled together, and a statistically significant difference was found between CVm (\%), Thin Place $(-40 \% / \mathrm{km})$ and Thick Place $(+35 \% / \mathrm{km})$ values of the carded yarns produced by using $28 \mathrm{~mm}$ and $30 \mathrm{~mm}$ front and back cot diameter combinations on the ring spinning machine. There was no statistically significant difference in Neps $(+200 \% / \mathrm{km})$ values according to the cot diameter combinations of these yarns. In addition, when the diameter of the front collar is large, an increase in yarn quality has been observed regardless of the size of the back cot diameter. The findings obtained is expected to shed light on increasing the yarn quality in ring spinning mills.

Keywords: Ring spinning machine, Cotton, Cot Diameter, Yarn Quality Parameters.

\section{Giriş}

Hammadde, süreç kontrol teknikleri ve eğirme parametreleri nihai iplik özelliklerini etkileyen ana faktörlerdir (Majumdar \& Majumdar, 2004; Lawrence, 2003). Ring iplik eğirme sisteminin çalışma prensipleri arasında çekim, büküm ve sarım adımları bulunmakta ve bu işlemlerin arasında bulunan çekim aşaması ipliğin kalite değerleri üzerinde önemli bir rol oynamaktadır (Khurshid ve ark., 2018). Çekim işlemi bileşenlerinin, özellikle de manşonun, ring iplik eğirme işleminde iplik kalitesi ve üretim maliyetleri üzerinde önemli bir etkisi vardır (Kane \& Ghalsasi, 1992). Manşon, liflerle doğrudan temas halinde olduğu için nihai iplik kalitesi üzerindeki etkisi önemlidir (Ghane, Semnani, Saghafi \& Beigzadeh, 2008).

Cer, penyöz, fitil ve ring makinalarında kullanılan manşon, lif üzerinde eşit basınç sağlayarak daha etkin bir çekim işlemi sağlar (Chakrabortty, Hasan, Ghosh, \& Redwanul, 2020). Ring iplikçiliğindeki ön manşonlar, ring eğirme işleminde yeterli çekme kuvveti oluşturmaktadır. Çekim direncinin üstesinden gelmek için, ön manşonda, lifler arasındaki sürtünme direncinin toplamından daha büyük veya ona eşit olan minimum çekme kuvveti ve apronların lifler üzerine uyguladığı kuvvet gerekmektedir (Akbar, Zeshan, Neaz, Cai, \& Lin, 2017). Ön manşon, pamuğun eğirme mukavemetini etkilemekte ve lif kohezyonunda (kaymaya karşı direnç) önemli bir rol oynamaktadır (Ghane ve ark., 2008). Süreç içerisinde, manşonların yüzeyleri zarar görebilmekte ve çevresinde çatlaklar oluşabilmektedir. Bu durum, çekim işlemi sırasında liflerin kaymasına neden olmakta ve önlem amaçlı manşonların yüzeyi bir taşlama makinası ile taşlanmaktadır. Bu taşlama işlemi sonucunda, manşon çapı küçülmekte ve bu da iplik kalitesi üzerinde bazı farklılıklara yol açmaktadır (Ghane ve ark., 2008). Xu (2005) manşon çap farklılıklarının iplik kalitesi üzerindeki etkisini araştırdığı çalışmasında, ön manşon çapının artmasıyla birlikte nihai iplik kalite parametrelerinin de iyileştiğini belirtmiştir. Benzer şekilde, Ghane ve ark. (2008), taşlama işlemi sonrası elde edilen optimum ön manşon çapının etkisini tahmin edebilmek adına bir algoritma 
geliştirdikleri çalışmalarında, manşon çapı ile iplik düzgünsüzlük değerleri arasında ters orantı olduğunu ve ön manşon çapı arttıkça iplikteki düzgünsüzlüğün azaldığını bulmuşlardır.

Manşon çeşitleri nihai iplik üzerinde farklı etkiler oluşturabilmektedir. Manşon seçiminde, işlenecek elyafın türü, üretilmesi planlanan ipliğin numarası, kullanım alanı, makine konstrüksiyonu ve işletmelerde kullanılan testler önemli rol oynamaktadır. $\mathrm{Bu}$ parametreler göz önünde bulundurularak, manşonların sertliği ve tipine göre seçim yapılmaktadır. Bu zamana kadar ring iplikçiliği üzerine yapılmış çalışmaların büyük çoğunluğu manşon sertliği üzerinde yoğunlaşmaktadır (Akbar ve ark., 2017; Bagwan, Policepatil \& Pawar, 2016; Chakrabortty ve ark., 2020; Ferede, 2017; Khurshid ve ark., 2018; Sujai \& Sivakumar, 2015).

Her ne kadar manşon sertliği hakkında birçok çalışma yapılmış olsa da, \% 100 pamuk lifinden üretilen karde ring ipliklerinin ön ve arka manşon çaplarına göre düzgünsüzlük ve IPI (İnce Yer, Kalın Yer ve Neps hataları) kalite parametrelerinin üzerindeki etkisini araştıran çalışmaların azlığı göze çarpmaktadır. Bununla birlikte, alanda yapılan çalışmalarda genel olarak, ring iplik eğirme makinasının çekim bölgesindeki ön manşon üzerine yoğunlaşılmış olup, bu çalışmada alandaki diğer çalışmalardan farklı olarak ön ve arka manşon birlikte ele alınmış olup, çap değerlerindeki değişimin, üretilen iplik kalitesine yaptığı etkinin belirlenmesi hedeflenmiştir.

İplik kalitesi, iplik işletmelerinin ekonomik başarısında ve bu başarının sürdürülmesinde önemli bir rol oynamaktadır. Uluslararası rekabet ve pazar gereklilikleri, kabul edilebilir bir fiyata daha kaliteli iplikler üretme gereğini belirlemektedir. (Akbar ve ark., 2017). Bu nedenle, daha iyi iplik kalite sonuçlarına ulaşmak amacıyla, iplik kalite parametrelerine etki eden unsurları araştırmak da büyük önem taşımaktadır. Bütün bunlar göz önünde bulundurulduğunda, bu çalışmanın amacı, ring iplik eğirme sistemindeki ön ve arka manşonun sahip olduğu çap kombinasyonlarının karde ring ipliğinin kalitesi üzerinde etkisini, üretilen iplik numaralarına göre ayrı ayrı incelemek ve aynı zamanda daha kaliteli iplik üretmek için hangi kombinasyonların daha iyi olduğunu belirlemeye çalışmaktır.

\section{Materyal ve Metot}

\subsection{Kullanılan Hammadde}

$\mathrm{Bu}$ çalışma kapsamında Ege yöresine ait pamuk elyafı kullanılmış olup, bu pamuk harmanının çeşitli yerlerinden alınarak toplanan pamuk elyaf numuneleri Uster HVI 1000 test sisteminde ölçüme tabi tutulmuştur. HVI test sistemi, Uster firması tarafından geliştirilen ve elyaf özelliklerinin 
belirlenmesinde kullanılan bir test cihazı olmakla birlikte, elyafın standardizasyonunda da büyük bir önem arz etmektedir. (Foulk \& Mcalister, 2002). Uster firmasının HVI test sistemini geliştirmesi, tek bir cihazda elyaf hakkında daha ayrıntılı bilgi edinmeyi ve bu bilgiler ışığında bir standart oluşturmayı mümkün hale getirmiştir (Bedez, 2012). Bu çalışma kapsamında, kullanılan Ege yöresine ait pamuk harmanının değişik yerlerinden 10 adet numune alınmış olup, alınan her numune için HVI test cihazında 3 adet ölçüm yapılmıştır. Bu ölçümler, $20 \pm 2^{\circ} \mathrm{C}$ sıcaklık ve $\% 65 \pm 2$ bağıl nem değerlerinde (standart atmosfer koşullarında), Isparta Mensucat A.Ş. iplik üretim tesisinin iplik laboratuvarında gerçekleştirilmiştir. Ölçümler sonucunda bulunan değerlerin ortalaması Tablo 1'de gösterilmiştir.

Tablo 1. Pamuk Elyafı Uster HVI 1000 Ölçüm Değerleri

\begin{tabular}{lll}
\hline & Ortalama & Std. Sapma \\
\hline Mikroner $(\mu \mathrm{g} /$ inch) & 4.70 & 0.08 \\
Üst yarı ortalama uzunluk $(\mathrm{mm})$ & 29,94 & 0,18 \\
Uniformite indeksi $(\%)$ & 82,9 & 0,8 \\
SFI $(\%)$ & 7,8 & 0,7 \\
Mukavemet $(\mathrm{g} / \mathrm{tex})$ & 32,4 & 0,6 \\
Uzama $(\%)$ & 4,4 & 0,1 \\
Beyazlık derecesi & 78,1 & 0,4 \\
Sarılık derecesi & 8,4 & 0,1 \\
Renk derecesi & $31-1$ & - \\
Çepel sayıs1 & 54 & 6 \\
\hline
\end{tabular}

Tablo 1'de Uster HVI 1000 test siteminde ölçülen değerler sıralanmaktadır. Tek başına bir anlam ifade etmese de, ştapel uzunluk, küçük bir pamuk tutamındaki liflerin, uzunluklarına göre yan yana sıralandıkları ve liflerin uzunluk dağılımını gösteren ştapel diyagramından elde edilen elyaf uzunluk değeri olarak tanımlanırken, üst yarı ortalama uzunluk ise ağırlık esasına göre liflerin \%50' sinden daha ağır olan liflerin ortalama uzunluklarını ifade etmektedir ve ticari alanda geçerli olarak kullanılan değerdir (Şahin, 2015). Uniformite indeksi değeri ise ştapel diyagramından elde edilen ortalama uzunluğun, üst yarı ortalama uzunluğa oranı olarak ifade edilmektedir. Lif uzaması, doğal haldeyken life bir kuvvet uygulandığında, lifin kopuncaya kadar bu kuvvete uzayarak karşı koymaya çalışırken, kopma olmadan kuvvet ortadan kaldırıldığında lifin tekrar eski haline dönme isteği olarak tanımlanırken, mukavemet ise lifin herhangi bir basınca maruz kaldığında kopmaya karşı koyduğu dayanma gücü olarak tanımlanmaktadır (Toprakçı, 2008). Çepel, pamuk elyafındaki bitki yaprak ve kabuğu gibi yabancı maddeleri ifade etmektedir. Çepel sayısının fazlalığına bağlı olarak renk derecesinde bir düşüş meydana gelebilmekte, renk derecesindeki bu düşüş, iyi bir kütlü temizleme düzenine sahip çırçırlama ile ortadan kaldırılabilmektedir. Pamuğun temizlik derecesi, pamuk fiyatını doğrudan etkileyen en önemli etkenlerden birisidir. (Erdal, 2006). 
HVI test sisteminde ölçülen değerlere bakıldığında, uzunluk dağılımının, kısa lif iplikçiliği açısından sınır değerler arasında olduğu tespit edilmiştir. Çalışma kapsamında kullanılan pamuk, 4.7 olarak ölçülen mikroner değeriyle "orta ince”, 29,94 üst yarı ortalama uzunluk değeriyle "orta uzun", \%82,9 uniformite indeksi değeriyle "yüksek" sınıfta yer almakta, mukavemet değerine göre “çok sağlam” lif grubunda bulunan liflerin, uzama yüzdesi ise "çok zayıf” olarak sınıflandırma tablosunda yer bulmaktadır. Buna ilave olarak kısa elyaf oranı (12.7 mm'den küçük elyaf \%'si) ise "düşük (iyi)" sınıfta bulunmuştur (Commercial Standardization of Instrument Testing of Cotton, 2020).

\subsection{Makina Parkuru}

Çalışmada kullanılmak üzere numune iplik üretimi Isparta Mensucat A.Ş. iplik üretim tesisinde gerçekleştirilmiş olup, Şekil 1' de, yine çalışmada kullanılmak üzere üretilen numunelerin üretiminin yapıldığı karde ring iplik üretim hattı makina parkuru gösterilmiştir.

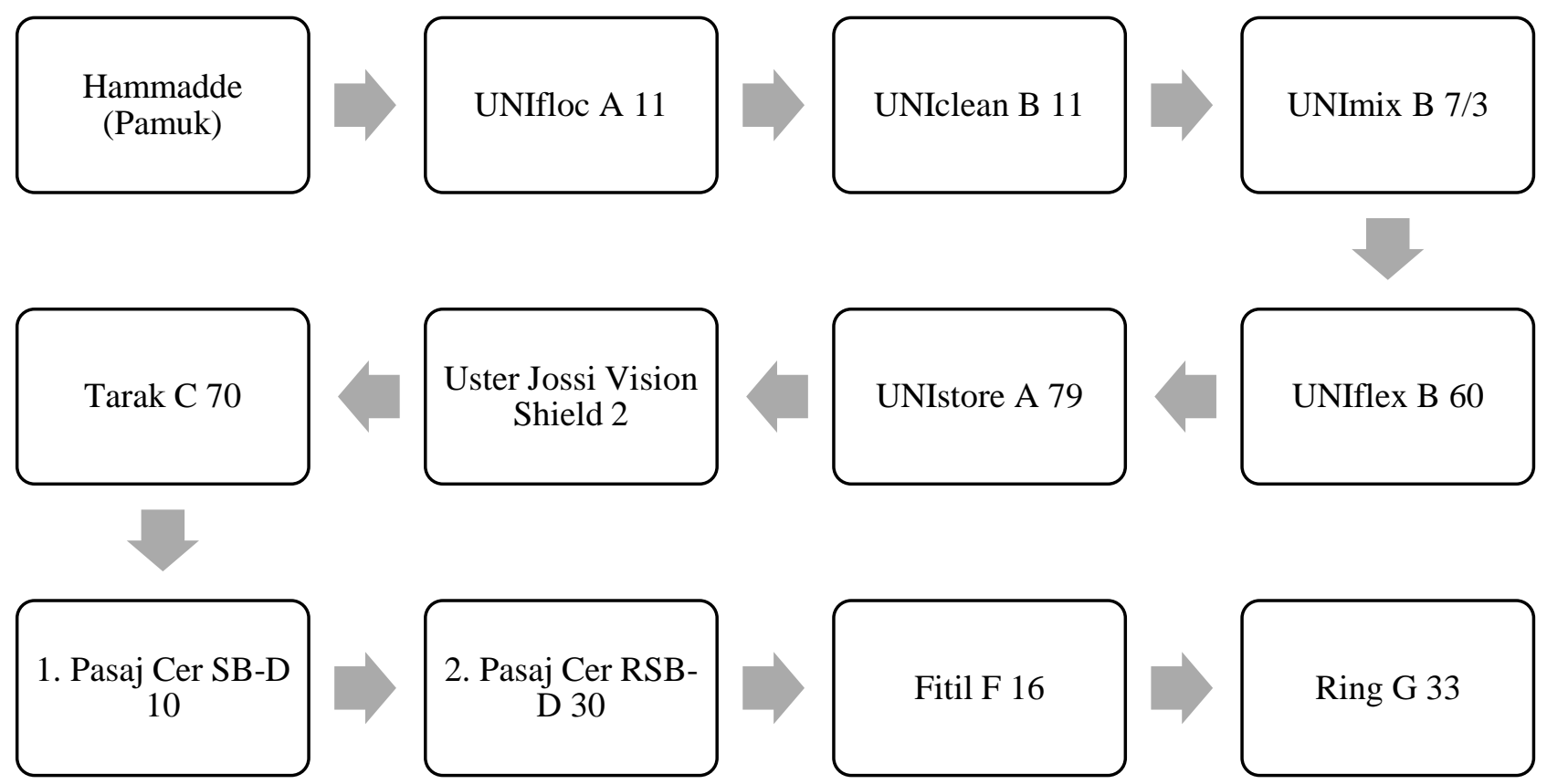

Şekil 1. Karde ring iplik makine hattı 
Ring iplik eğirme makinasında (G 33) bu çalışma için üretilen iplik numunelerinin üretim parametrelerine ait değerler Tablo 2'de gösterilmiştir.

Tablo 2. İplik Numune Üretiminde Kullanılan Parametreler

\begin{tabular}{lll}
\hline İplik numarası & İplik üretimindeki parametreler & \\
& Tarak, 1. ve 2. Pasaj Cer Şerit Numarası (Ne) & 0,120 \\
& Fitil numarası (Ne) & 0,90 \\
\multirow{3}{*}{$\mathrm{Ne} 20 / 1$} & Fitil bükümü (T/inch) & 1,20 \\
& İplik bükümü (T/m) & 680 \\
& Ortalama ring devri (d/dak.) & 12500 \\
& Ring kopça tipi ve ISO numaras1 & PM Udr Safir - 56 \\
& Ring klips numarası (mm) & 3,75 \\
\hline & Tarak, 1. Ve 2. Cer Şerit Numarası (Ne) & 0,120 \\
& Fitil numarası (Ne) & 0,90 \\
$\mathrm{Ne} 40 / 1$ & Fitil bükümü (T/inch) & 1,20 \\
& İplik bükümü (T/m) & 962 \\
& Ortalama ring devri (d/dak.) & 15000 \\
& Ring kopça tipi ve ISO numaras1 & PM Udr Safir - 31,5 \\
& Ring klips numarası (mm) & 2,5 \\
\hline
\end{tabular}

Numune üretiminde, kullanılan harmandan 10 adet ve her biri 2000 metre uzunluğa sahip fitil üretimi gerçekleştirilmiş olup, bu fitillerden, piyasada en çok üretilen ince ve kalın numaraların karşıllğ̆ olarak Ne 20/1 ve Ne 40/1 numaralarında, her bir çap kombinasyonu için 10' ar adet olmak üzere ring iplik eğirme makinasında toplam 80 adet kops üretimi gerçekleştirilmiştir. Ring iplik eğirme makinasında üretilen karde ring ipliklerin kops halinde Uster Tester 4 cihazıyla yapılan ölçümlerinde farklı sonuçların çıkmasına sebep olabilecek makina kaynaklı nedenlerin giderilmesi amacıyla üretilen numuneler, fitil ve ring iplik eğirme makinalarının aynı iğleri kullanılarak üretim gerçekleştirilmiştir.

\subsection{Kullanılan Manşonlar}

$\mathrm{Bu}$ çalışma için ring iplik eğirme makinasının (G33) çekim bölgesinde, daha uzun süreli kullanım ve geniş iplik numara yelpazesinde üretim yapılabilmesi nedeniyle, Saurer firmasına ait Accotex markalı manşonlar kullanılmıştır. Kısa lif iplikçiliğinde çoğunlukla tercih edilen ve Saurer firmasının geniş numara aralıklarında ( $\mathrm{Ne} 20 / 1^{\prime}$ den $\mathrm{Ne}$ 50/1' e kadar) üretim yapmak isteyen iplik işletmelerine önerdiği; önde 63, arkada ise 83 shore sertlik derecesine sahip mor ve gri renkli manşonlarla kops üretimi gerçekleştirilmiştir. 
Ring iplik eğirme sisteminde, arka manşon olarak kullanılan ve daha sert bir yapıda olan gri renkli manşon, üretici firma (Saurer) tarafından önerilen 1500 saatlik bir taşlama periyoduna ve her bir taşlama işleminde $0,15 \mathrm{~mm}$ ' lik bir çap değeri azalmasına sahiptir. Yine ring iplik eğirme sisteminde ön manşon olarak kullanılan ve arka manşona göre daha yumuşak bir yapıda olan mor renkli manşon, üretici firma (Saurer) tarafından önerilen 750 saatlik bir taşlama periyoduna sahip olup, her bir taşlama işleminde ise çap değerinden 0,20 mm kaybetmektedir. Taşlama miktarı farklılığı, manşonların sertlik derecesine bağlı olup, özellikle sert manşonlarda daha yüksek taşlama miktarı, manşonun aşırı ısınarak, yüzey yapısının bozulmasına yol açabilmektedir. Manşon sertlik değerlerinden kaynaklanan taşlama periyodunun ve taşlama miktarının farklı olması, zamanla ön ve arka manşonlar için bir çap varyasyonunu beraberinde getirmektedir. Ring iplik eğirme makinasında (G 33) bu çalışma için kullanılan manşon özellikleri ve kombinasyonları Tablo 3 'de gösterilmiştir.

Tablo 3. Çalışmada Kullanılan Manşon Çap Kombinasyonları ve Özellikleri

\begin{tabular}{ccccccc}
\hline \multirow{2}{*}{$\begin{array}{c}\text { Manşon } \\
\text { Kombinasyonları }\end{array}$} & Renk & Ön Manşonon & \multicolumn{3}{c}{ Arka Manşon } \\
\hline K-1 & Mor & 63 & 30 & Gri & 83 & 30 \\
\hline K-2 & Mor & 63 & 30 & Gri & 83 & 28 \\
\hline K-3 & Mor & 63 & 28 & Gri & 83 & 30 \\
\hline K-4 & Mor & 63 & 28 & Gri & 83 & 28 \\
\hline
\end{tabular}

Tablo 3' de görüldüğü üzere çalışmada dört farklı manşon kombinasyonu kullanılmıştır. Bu çalışma kapsamında kullanılan ön ve arka manşonlar, $30 \mathrm{~mm}$ ve $28 \mathrm{~mm}$ çap değerlerine sahip olup, $30 \mathrm{~mm}$ çap değeri yeni kullanılacak manşonun taşlama sonrası çapını, $28 \mathrm{~mm}$ ise kullanım ömrünü tamamlamak üzere olan manşon çap değerini yansıtması açısından seçilmiştir.

\subsection{Veri Analizi}

Ne 20/1 ve Ne 40/1 numara karde ring iplik numunelerinin düzgünsüzlük CVm (\%) ve IPI (imperfection index) ölçümleri Uster Tester 4 test cihazı ile gerçekleştirilmiştir.

CVm (\%) değeri; bir materyalin ölçüme tabi tutulan uzunluğu boyunca olan toplam kütle varyasyonunun büyüklüğ̈nü ifade etmektedir (Thilagavathi \& Karthik, 2016). Uster Tester 4 test cihazı şerit, fitil ve iplik numunelerinin düzgünsüzlük ve hata ölçümlerini, sabit hız ile kondansatör plakaları arasından geçirerek yapmaktadır. Materyal kütlesindeki değişim kondansatör sığasını 
değiştirmekte, böylece CVm (\%) değerleri ölçülmüş olmaktadır. Yine cihaz üzerinde bulunan spektograf ünitesi, tekrar eden, büyüklük ve dalga boyları aynı olan hataları sınıflandırıp IPI değeri olarak belirtmektedir (Kat1, 2004).

IPI ifadesi, kesikli liflerden yapılan ipliklerde görülen hatalar olan, İnce Yer, Kalın Yer ve Neps hatalarını içermektedir. İnce Yer $(-\% 40 / \mathrm{km})$ değeri, ortalama iplik kesitinin \%40'ına kadar olan iplik kesitlerinin km'deki adedi olarak tanımlanırken, Kalın Yer $(+\% 35 / \mathrm{km})$ değeri ise ortalama iplik kesitinin \%135'sine kadar olan iplik kesitlerinin km'deki adedi olarak tanımlanmaktadır. Neps (+\%200) değeri ise ortalama iplik kesitinin \%300’ü büyüklüğündeki yerler olarak ifade edilmektedir (Thilagavathi \& Karthik, 2016). Uster Tester 4 cihazının IPI ölçüm sonuçları için farklı hassasiyet ayarları bulunmaktadır. Piyasada genellikle İnce Yer (-\%50/km) ve Kalın Yer (+\%50/km) hassasiyet kullanımı söz konusu iken kaliteye önem veren ve bu doğrultuda üretim yapan firmalar açısından bir üst hassasiyet derecesi olan İnce Yer (-\%40/km) ve Kalın Yer $(+\% 35 / \mathrm{km})$ değerleri büyük önem arz etmektedir. Bu çalışma kapsamında da bu değerlerin kullanımı, gerek ölçüm hassasiyetinin artması gerekse bu artışın sonuçlar arasındaki farkı daha belirgin hale getirmesinden dolayı tercih edilmiştir.

Çalışmada üretilen iplik numunelerinin Uster Tester 4 test cihazı ile ölçüme tabi tutulmasıyla elde edilen veriler istatistik programı kullanılarak analiz edilmiştir. Manşon çapı kombinasyonlarının nihai iplik CVm (\%), İnce Yer $(-\% 40 / \mathrm{km})$, Kalın Yer $(+\% 35 / \mathrm{km})$ ve Neps (+\%200/km) değerlerine etkisi olup olmadığını araştırmak amacıyla Tek Yönlü ANOVA istatiksel analiz yöntemi kullanılmıştır. Ayrıca, yukarıda belirtilen iplik kalite değerleri açısından hangi manşon çapı kombinasyonları arasında anlamlı farkın bulunduğunu tespit etmek amacıyla LSD Post Hoc analizine başvurulmuştur.

\section{Bulgular}

\subsection{Ne 20/1 karde iplik ölçüm ve analiz sonuçları}

\subsubsection{Düzgünsüzlük ölçümlerine ait sonuçlar}

Ne 20/1 numarada üretilen karde ring ipliklerine ait düzgünsüzlük ortalama değerlerinin grafikleri Şekil 2' de sunulmuştur. 


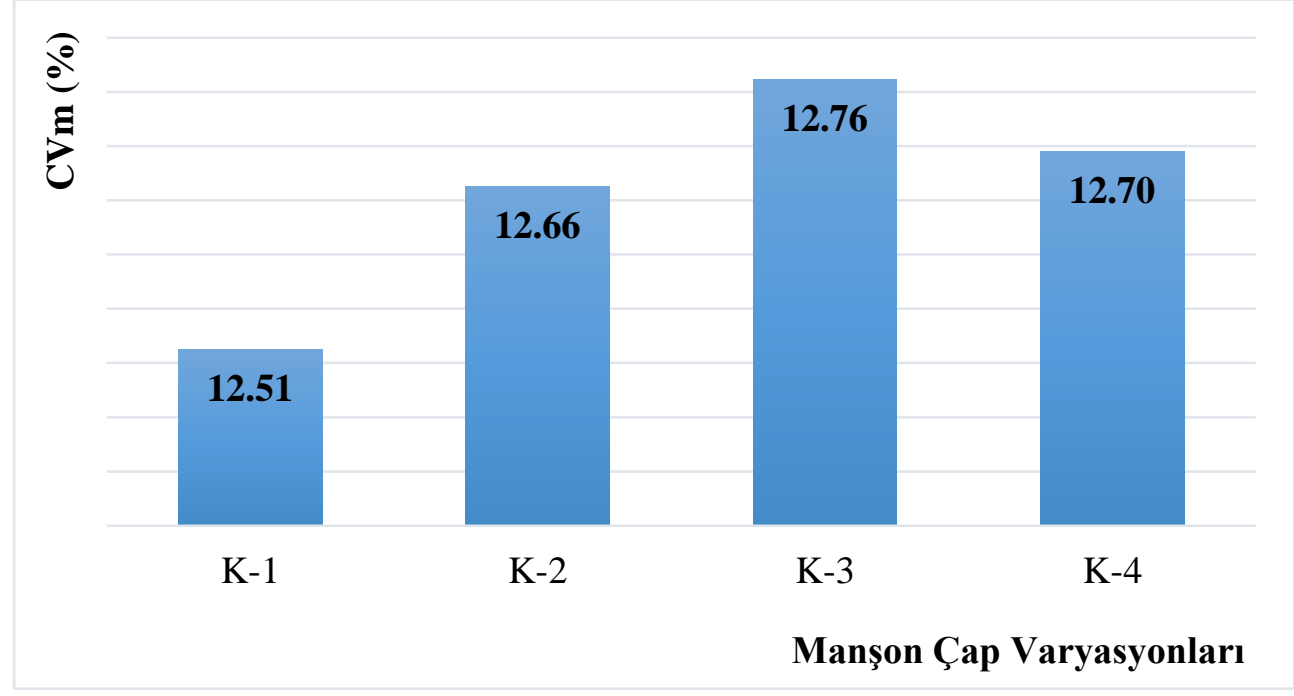

Şekil 2. Ne 20/1 CVm (\%) ortalama değerler grafiğgi

Ne 20/1 numarada, 4 farklı ön ve arka manşon çapı kombinasyonlarında üretilen karde ring iplik numunelerine ait düzgünsüzlük $(\mathrm{CVm}(\%))$ değer ortalamaları Şekil 2' de verilmiştir. Buna göre, mor renkli ve $30 \mathrm{~mm}$ çapa sahip olan manşonun ön kısımda yer alması, $28 \mathrm{~mm}$ çapa sahip olan manşonun ön manşon olarak kullanılmasına kıyasla, üretilen ipliğin daha düşük CVm (\%) ortalama değerine sahip olmasına neden olmuştur. Ön manşon çapı $30 \mathrm{~mm}$ ile sabit kaldığında, arka manşon çapının azalması CVm (\%) değerinin artmasına neden olurken, ön manşon çapının 28 mm ile sabit kalması durumunda arka manşon çap değişiminin bu değerler üzerinde çok fazla bir etkisinin olmadı̆̆ söylenebilir. Diğer bir ifadeyle, $28 \mathrm{~mm}$ çap değerine sahip ön manşonun bulunduğu çap kombinasyonlarının (K-3 ve K-4), arka manşon çapına bakılmaksızın, daha yüksek CVm (\%) sonuçlarına neden olduğu görülmektedir.

\subsubsection{IPI ölçümlerine ait sonuçlar}

Ne 20/1 numarada üretilen karde ring ipliklerine ait IPI ölçümlerine ait ortalama değerlerinin grafikleri Şekil 3,4 ve 5' de sunulmuştur. 


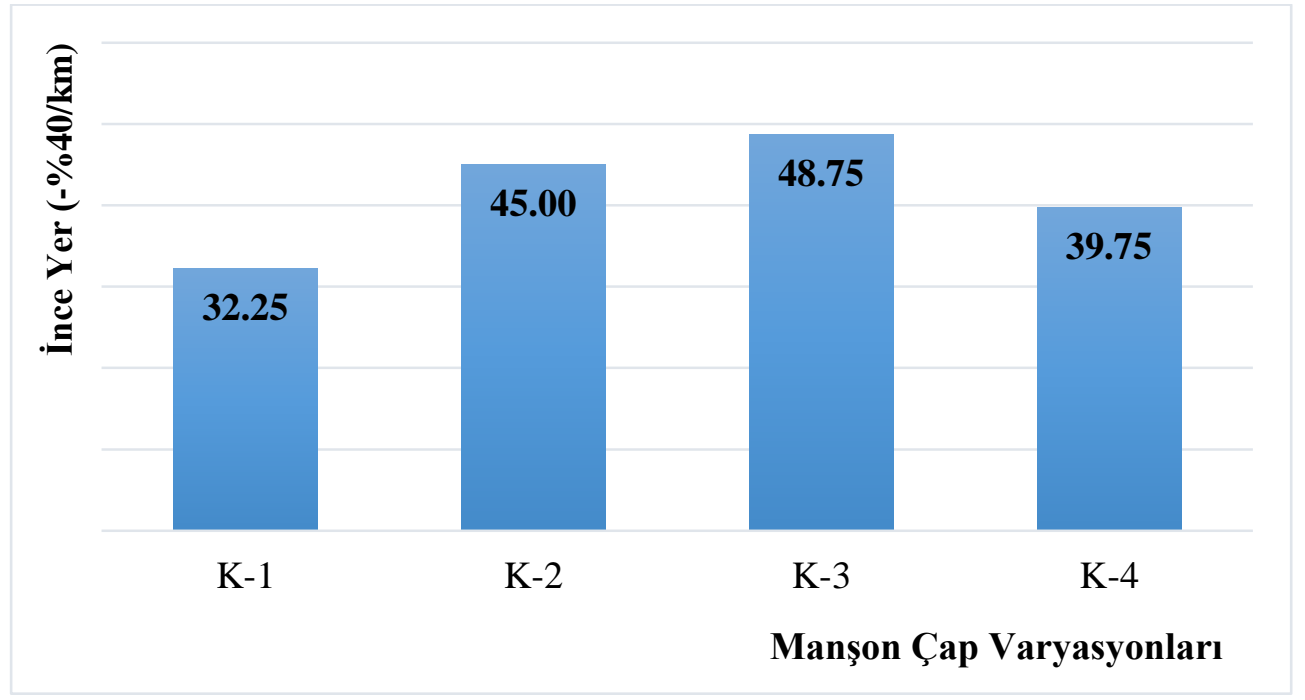

Şekil 3. Ne 20/1 İnce Yer (-\%40/km) ortalama değerler grafiği

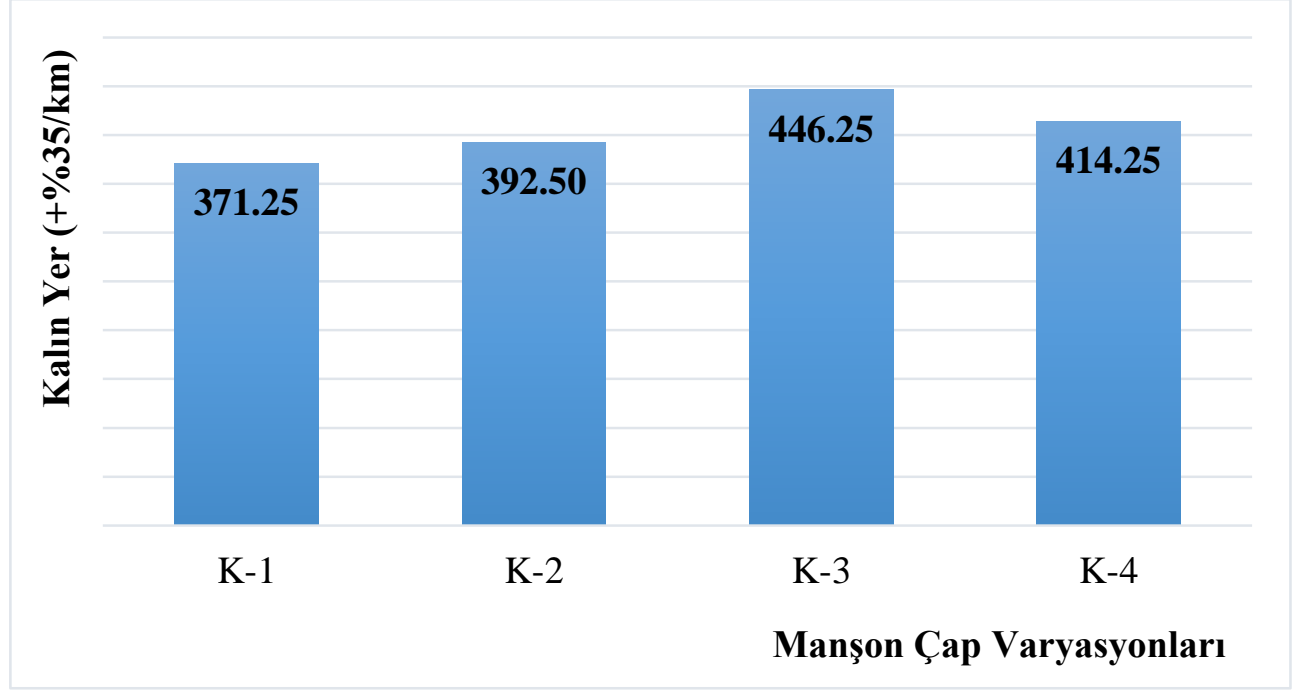

Şekil 4. Ne 20/1 Kalın Yer (+\%35/km) ortalama değerler grafiği

Şekil 3 ve Şekil 4'e bakıldığında Ne 20/1 numarada üretilmiş karde ring ipliklerin İnce Yer ($\% 40 / \mathrm{km})$ ve Kalın Yer $(+\% 35 / \mathrm{km})$ ortalama değerlerinin manşon çap kombinasyonlarına göre benzer eğriler çizdikleri görülmektedir. Buna göre, üretilmiş olan Ne 20/1 karde ipliklerinin arasında, İnce Yer (-\%40/km) hataları bakımından daha iyi ölçüm sonuçlarının, hem ön hem de arka manşon çapı büyük olan kombinasyondan elde edildiği söylenilebilir. Benzer şekilde, bu manşon çapı kombinasyonuna sahip Ne 20/1 karde ipliklerin Kalın Yer $(+\% 35 / \mathrm{km})$ hatalarının da diğer kombinasyonlara kıyasla daha düşük olduğu görülmektedir. Ön manşonda, taşlama işlemiyle ortaya çıkan çap değerindeki azalma, İnce Yer $(-\% 40 / \mathrm{km})$ ve Kalın Yer $(+\% 35 / \mathrm{km})$ hatalarında artışı da 
beraberinde getirmektedir. En yüksek düzgünsüzlük oranları K-3 manşon çapı kombinasyonunda gözlemlenmektedir.

Neps $(+\% 200 / \mathrm{km})$ ortalama değerlerine ait ortalama değerler grafiği Şekil 5' de sunulmuştur.

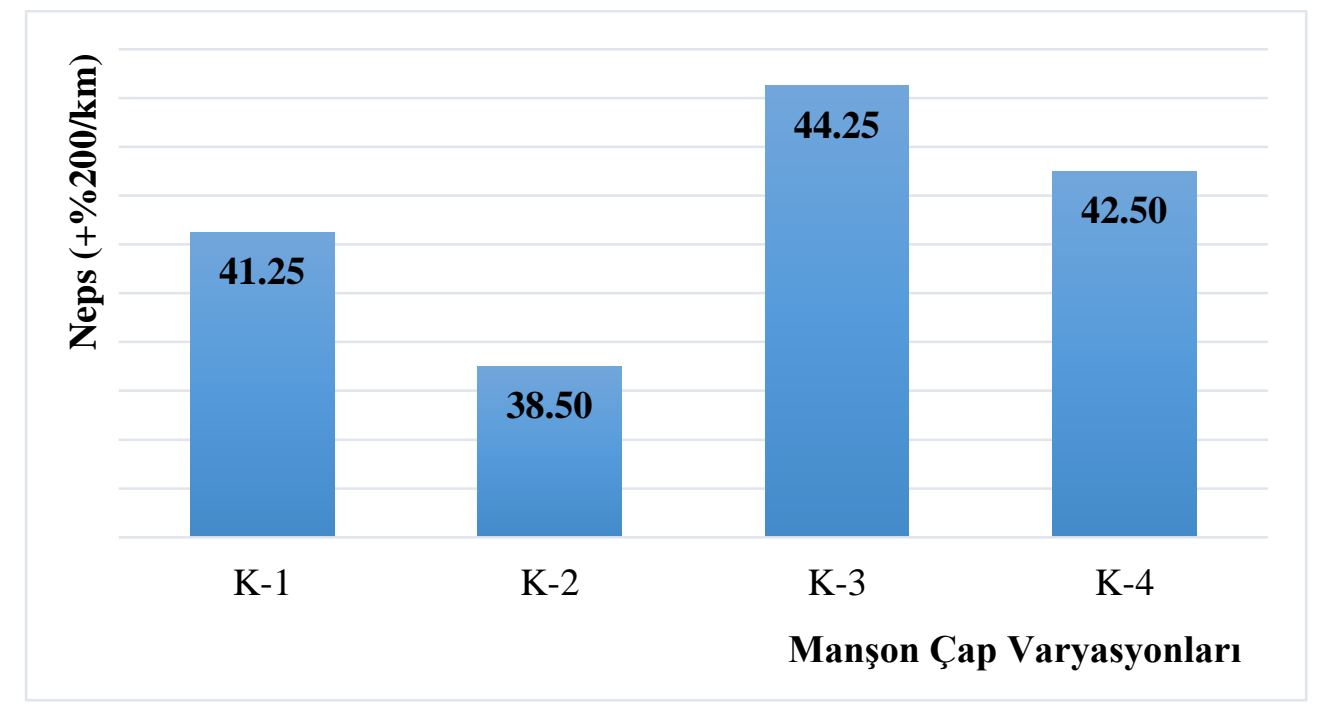

Şekil 5. Ne 20/1 Neps (+\%200/km) ortalama değerler grafiği

Ne 20/1 karde ring ipliklerin manşon çapına göre Neps $(+\% 200 / \mathrm{km})$ ortalama değerleri Şekil 5' de incelendiğinde, ön manşondaki çap artışı ile birlikte neps değerlerinde bir azalma gözlemlenmektedir. Arka manşon çapının iplik neps değerleri üzerindeki etkisine bakıldığında ise manşon çap değeri azalmasının, neps değerlerinde nispi bir düşüşe neden olduğu bulunmuştur. Fakat ANOVA analizi sonuçlarında da bahsedildiği üzere, manşon çapı varyasyonlarına ait neps değerleri arasındaki farkın anlamlı olmadığı sonucuna ulaşılmıştır.

\subsubsection{Düzgünsüzlük analiz sonuçları}

Manşon çap kombinasyonlarının Ne 20/1 karde ring ipliği düzgünsüzlük değeri üzerinde bir etkisinin olup olmadığını araştırmak amacıyla Tek Yönlü ANOVA analizi yapılmıştır. Analiz sonuçları Tablo 4'te verilmiştir. 
Zeybek, A., Uluslararası Doğu Anadolu Fen Mühendislik ve Tasarım Dergisi / International Journal of Eastern Anatolia Science Engineering and Design (IJEASED)

(2020) 2(2):380-400

Tablo 4. Manşon Çap Kombinasyonlarına Göre Ne 20/1 Karde Ring İpliği Düzgünsüzlük Değerleri ANOVA Analizi Sonuçlar

\begin{tabular}{lllllll}
\hline & & Kareler Toplamı & df & Kareler Ortalamas1 & F & p. \\
\hline CVm (\%) & Gruplararas1 & 0,332 & 3 & 0,111 & 2,955 & $0,045^{*}$ \\
& Grupiçi & 1,349 & 36 & 0,037 & & \\
& Toplam & 1,682 & 39 & & & \\
\hline
\end{tabular}

*: 0.05 seviyesinde istatistiksel açıdan anlamlı bir fark vardır.

Tablo 4'ten de görülebileceği üzere, çalışmada kullanılan manşon çap kombinasyonları, $\mathrm{Ne}$ 20/1 numara ipliklerin CVm (\%) değeri üzerinde istatistiki açıdan anlamlı bir etkiye sahiptir $(\mathrm{p}<.05)$.

Ne 20/1 numara ipliklerin, CVm (\%) değeri üzerindeki anlamlı farkların hangi manşon çapı grupları arasında olduğunu belirlemek için LSD post hoc analizi yapılmış olup elde edilen sonuçlar Tablo 5’te verilmiştir.

Tablo 5. Ne 20/1 Karde Ring İpliği Düzgünsüzlük Değeri LSD Sonuçları

\begin{tabular}{|c|c|c|c|c|c|}
\hline \multirow{2}{*}{$\mathrm{CVm}(\%)$} & \multicolumn{2}{|c|}{ Manşon Çap Grupları } & \multirow{2}{*}{$\begin{array}{l}\text { Ortalama Fark } \\
-0,15000\end{array}$} & \multirow{2}{*}{$\begin{array}{l}\text { Std. Hata } \\
0,08658\end{array}$} & \multirow{2}{*}{$\begin{array}{l}\mathrm{p} \\
0,092\end{array}$} \\
\hline & $\mathrm{K}-1$ & $\mathrm{~K}-2$ & & & \\
\hline & & $\mathrm{K}-3$ &,$- 24900^{*}$ & 0,08658 & $0,007 *$ \\
\hline & & K-4 &,$- 18200^{*}$ & 0,08658 & $0,043^{*}$ \\
\hline & $\mathrm{K}-2$ & K-3 & $-0,09900$ & 0,08658 & 0,260 \\
\hline & & $\mathrm{K}-4$ & $-0,03200$ & 0,08658 & 0,714 \\
\hline & K-3 & K-4 & 0,06700 & 0,08658 & 0,444 \\
\hline
\end{tabular}

*: 0.05 seviyesinde istatistiksel açıdan anlamlı bir fark vardır.

Dört farklı manşon çapı kombinasyonlarına göre üretilen ipliklerde en yüksek CVm (\%) değeri ortalaması K-3 manşon çapı grubunda (\% 12,76) olup, en düşük CVm (\%) değeri K-1 manşon çapı grubunda (\% 12,51) gözlemlenmiştir. Bununla birlikte CVm (\%) değeri için LSD post hoc sonuçları K-1 ile K-3 ve K-1 ile K-4 manşon grupları arasında anlamlı bir fark olduğunu göstermektedir.

\subsubsection{IPI analiz sonuçları}

Manşon çap kombinasyonlarının Ne 20/1 karde ring ipliği IPI değerleri üzerinde bir etkisinin olup olmadığını araştırmak amacıyla Tek Yönlü ANOVA analizi yapılmıştır. Analiz sonuçları Tablo 6' da verilmiştir. 
Tablo 6. Manşon Çap Kombinasyonlarına Göre Ne 20/1 Karde Ring İpliği IPI Değerleri ANOVA Analizi Sonuçları

\begin{tabular}{lllllll}
\hline & & Kareler Toplam1 & df & Kareler Ortalamas1 & F & p. \\
\hline İnce Yer (-\%40/km) & Gruplararas1 & 1534,219 & 3 & 511,406 & 3,626 & $0,022^{*}$ \\
& Grupiçi & 5076,875 & 36 & 141,024 & & \\
& Toplam & 6611,094 & 39 & & & \\
\hline Kalın Yer (+\%35/km) & Gruplararas1 & 30779,219 & 3 & 10259,740 & 3,195 & $0,035^{*}$ \\
& Grupiçi & 115594,375 & 36 & 3210,955 & & \\
& Toplam & 146373,59375 & 39 & & & \\
\hline Neps (+\%200/km) & Gruplararas1 & 175,625 & 3 & 58,542 & 0,444 & 0,723 \\
& Grupiçi & 4743,750 & 36 & 131,771 & & \\
& Toplam & 4919,375 & 39 & & & \\
\hline
\end{tabular}

*: 0.05 seviyesinde istatistiksel açıdan anlamlı bir fark vardır.

Tablo 6' da görülebileceği üzere, çalışmada kullanılan manşon çap kombinasyonları, Ne 20/1 numara ipliklerin İnce Yer $(-\% 40 / \mathrm{km})$ ve Kalın Yer $(+\% 35 / \mathrm{km})$ değerleri üzerinde istatistiki açıdan anlamlı bir etkiye sahiptir $(\mathrm{p}<.05)$. Neps $(+\% 200 / \mathrm{km})$ değeri üzerinde, kullanılan manşon çap kombinasyonları istatistiki açıdan herhangi anlamlı bir etkiye sahip değildir.

Ne 20/1 numara ipliklerin, İnce Yer (-\%40/km) ve Kalın Yer (+\%35/km) değerleri üzerindeki anlamlı farkların hangi manşon çapı grupları arasında olduğunu belirlemek için LSD post hoc analizi yapılmış olup elde edilen sonuçlar Tablo 7'de verilmiştir.

Tablo 7. Ne 20/1 Karde Ring İpliği IPI Değerleri LSD Sonuçları

\begin{tabular}{|c|c|c|c|c|c|}
\hline \multirow{2}{*}{ İnce Yer (-\%40/km) } & \multicolumn{2}{|c|}{ Manşon Çap Grupları } & \multirow{2}{*}{$\begin{array}{l}\text { Ortalama Fark } \\
-12,75000^{*}\end{array}$} & \multirow{2}{*}{$\begin{array}{l}\text { Std. Hata } \\
5,31082\end{array}$} & \multirow{2}{*}{$\begin{array}{l}\mathrm{p} \\
0,022^{*}\end{array}$} \\
\hline & $\mathrm{K}-1$ & $\mathrm{~K}-2$ & & & \\
\hline & & $\mathrm{K}-3$ & $-16,50000^{*}$ & 5,31082 & $0,004^{*}$ \\
\hline & & $\mathrm{K}-4$ & $-7,50000$ & 5,31082 & 0,166 \\
\hline & $\mathrm{K}-2$ & K-3 & $-3,75000$ & 5,31082 & 0,485 \\
\hline & & K-4 & 5,25000 & 5,31082 & 0,329 \\
\hline & $\mathrm{K}-3$ & K-4 & 9,00000 & 5,31082 & 0,099 \\
\hline \multirow[t]{6}{*}{ Kalın Yer $(+\% 35 / \mathrm{km})$} & $\mathrm{K}-1$ & K-2 & $-21,25000$ & 25,34149 & 0,407 \\
\hline & & K-3 & $-75,00000^{*}$ & 25,34149 & $0,005^{*}$ \\
\hline & & $\mathrm{K}-4$ & $-43,00000$ & 25,34149 & 0,098 \\
\hline & K-2 & K-3 & $-53,75000^{*}$ & 25,34149 & $0,041^{*}$ \\
\hline & & K-4 & $-21,75000$ & 25,34149 & 0,396 \\
\hline & K-3 & $\mathrm{K}-4$ & 32,00000 & 25,34149 & 0,215 \\
\hline
\end{tabular}

*: 0.05 seviyesinde istatistiksel açıdan anlamlı bir fark vardır. 
İnce Yer (-\%40/km) değeri için LSD post hoc sonucuna bakıldığında, K-1 ile K-2 ve K-1 ile K-3 manşon grupları arasında anlamlı bir fark bulunduğu ve bununla birlikte, K-1 manşon çapı grubunun en düşük İnce Yer (-\%40/km) değerine sahip olduğu görülmektedir.

Kalın Yer $(+\% 35 / \mathrm{km})$ değerleri için LSD post hoc sonuçlarına bakıldığında ise K-1 manşon çapı grubu ortalama değeri ile K-3 manşon çapı grubunun Kalın Yer (+\%35/km) ortalama değerleri arasında anlamlı bir fark bulunmuştur. Ayrıca yine Kalın Yer $(+\% 35 / \mathrm{km})$ ortalama değerlerine bakıldığında, K-2 manşon çapı grubu ile K-3 manşon çapı grubunun ortalama değerleri arasında anlamlı bir farkın olduğu görülmektedir. Diğer kalite değerlerinde olduğu gibi, K-1 manşon çapı grubunun en düşük Kalın Yer $(+\% 35 / \mathrm{km})$ ortalama değerine sahip olduğu gözlemlenmiştir.

\subsection{Ne 40/1 karde iplik ölçüm ve analiz sonuçları}

\subsubsection{Düzgünsüzlük ölçümlerine ait sonuçlar}

Ne 40/1 numarada üretilen karde ring ipliklerine ait düzgünsüzlük ortalama değerlerinin grafikleri Şekil 6' da sunulmuştur.

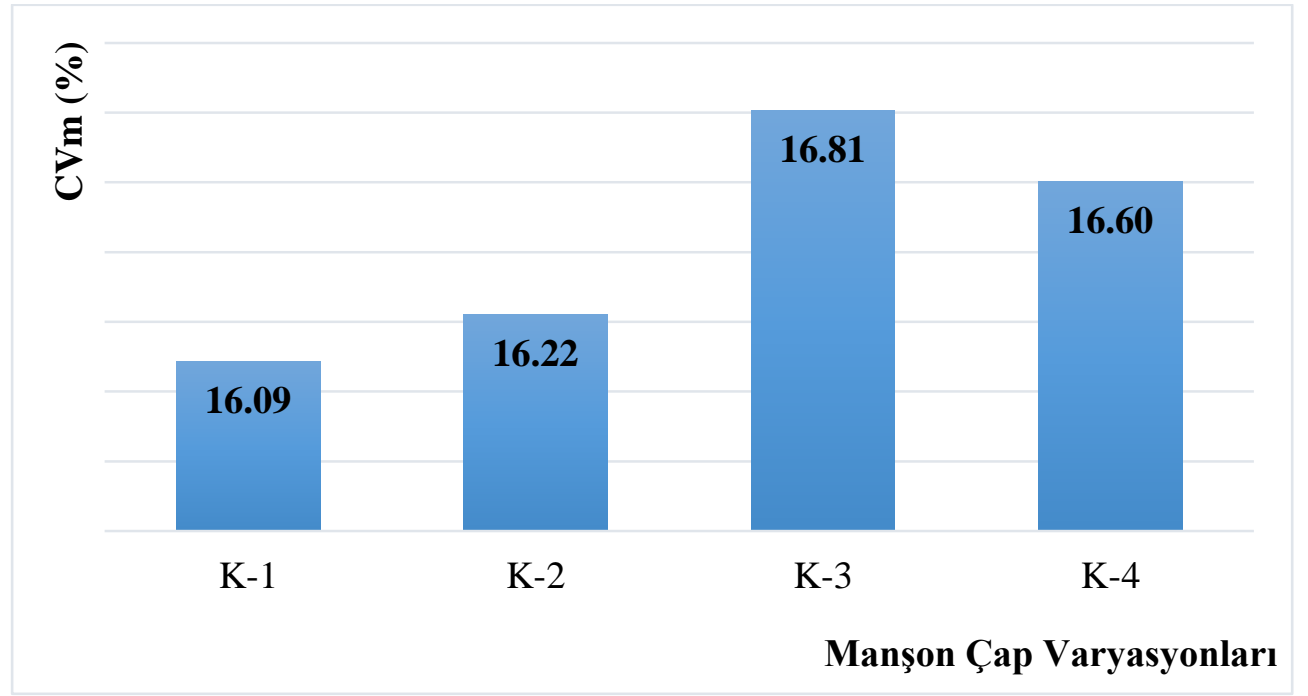

Şekil 6. Ne 40/1 CVm (\%) ortalama değerler grafiği

Ne 40/1 numarada üretilmiş ipliklerin manşon çapı kombinasyonlarına göre düzgünsüzlük (CVm (\%)) ortalama değerleri Şekil 6' da incelendiğinde, ön manşon çapının artışı ile ölçülen CVm (\%) değerlerinin düşüş yaşadığı görülebilmektedir. Ayrıca, Ne 20/1 karde ring ipliğine benzer şekilde, $\mathrm{Ne}$ 40/1 numara ipliklerde de ön manşon çap1 $30 \mathrm{~mm}$ ile sabit kaldığında, arka manşon çapının azalması CVm (\%) değerlerinde bir artışa neden olduğu bulunmuştur. Ön manşon çapının 
$28 \mathrm{~mm}$ ile sabit kalması durumunda ise arka manşonun bu değerler üzerinde çok fazla bir etkisinin olmadığı söylenebilir.

\subsubsection{IPI ölçümlerine ait sonuçlar}

Ne 40/1 numarada üretilen karde ring ipliklerine ait IPI ölçümlerine ait ortalama değerlerinin grafikleri Şekil 7,8 ve 9’ da sunulmuştur.

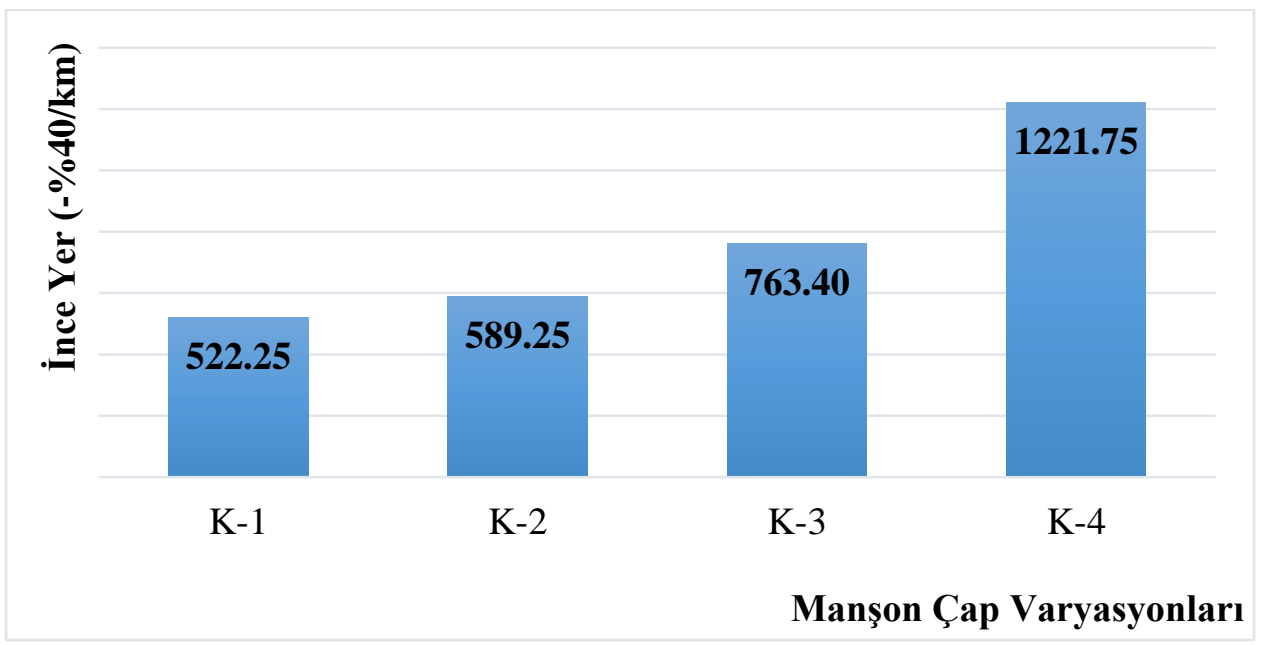

Şekil 7. Ne 40/1 İnce Yer (-\%40/km) ortalama değerler grafiği

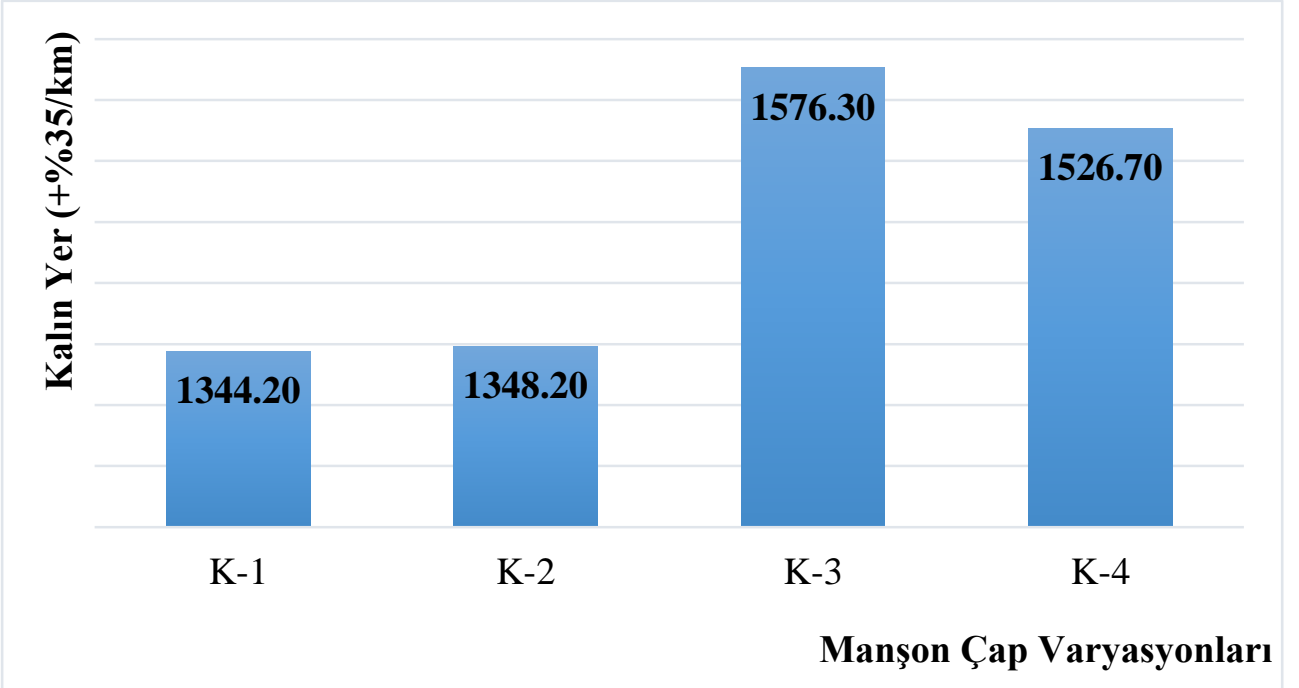

Şekil 8. Ne 40/1 Kalın Yer (+\%35/km) ortalama değerler grafiği 
Şekil 7 ve Şekil 8' de belirtilen İnce Yer (-\%40/km) ve Kalın Yer (+\%35/km) ortalama değerleri incelendiğinde, $\mathrm{Ne}$ 40/1 karde ring ipliklerin İnce Yer (-\%40/km) değerlerinde, hem ön hem de arka manşon çap değerlerinin azalmasıyla İnce Yer (-\%40/km) hatalarının artması doğru bir orantıda gerçekleşmiştir. Bu durumda, manşon çapı, özellikle de ön manşonun çapı arttıkça, $\mathrm{Ne}$ 40/1 numaralı iplikte daha az İnce Yer $(-\% 40 / \mathrm{km})$ hatalarına rastlandığı söylenebilir. Bununla birlikte, her ne kadar İnce Yer (-\% 40/km) hatalarında olduğu gibi doğrusal bir artış göstermese de, manşon çapının azalmasıyla birlikte Kalın Yer $(+\% 35 / \mathrm{km})$ hatalarına da daha sık rastlandı̆̆ görülmüştür. Özellikle Kalın Yer $(+\% 35 / \mathrm{km})$ değerleri açısından düşünüldüğünde, ön manşon çapının hatasızlık oranına ciddi bir etki yaptığı söylenebilmektedir.

Neps (+\%200/km) ortalama değerlerine ait ortalama değerler grafiği Şekil 9' da sunulmuştur.

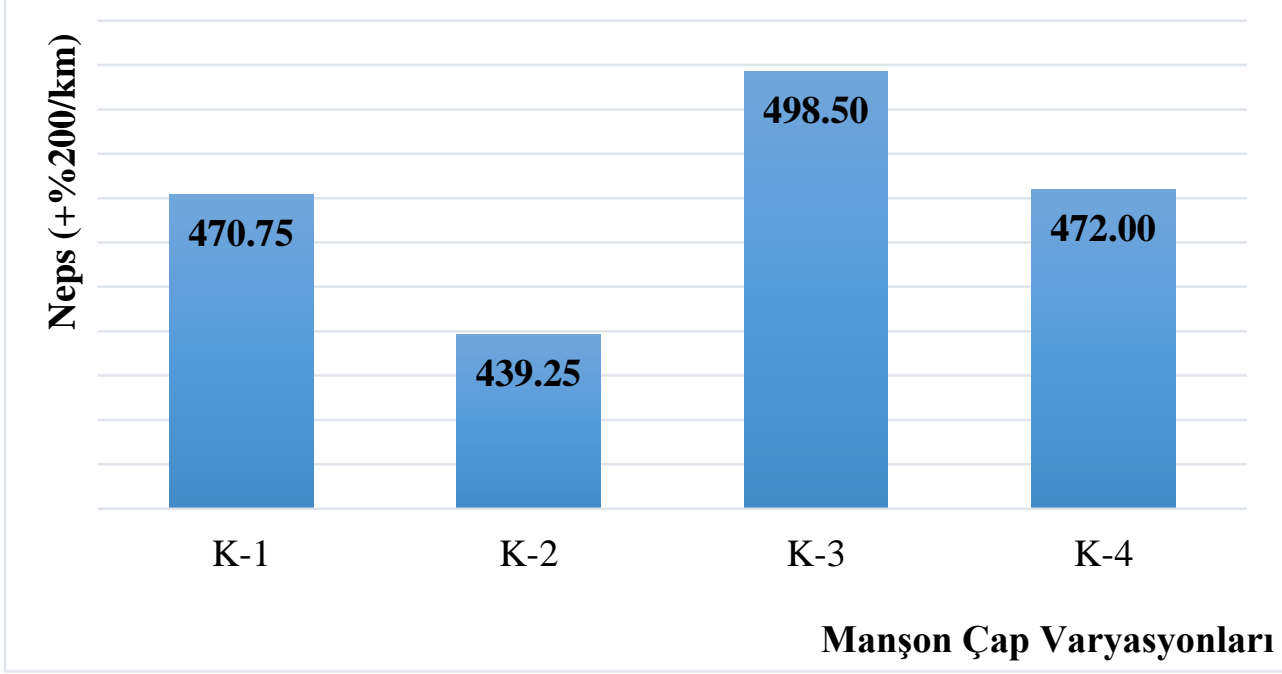

Şekil 9. Ne 40/1 Neps $(+\% 200 / \mathrm{km})$ ortalama değerler grafiği

Ne 40/1 numarada dört farklı manşon çapı varyasyonlarına göre üretilmiş olan karde ring ipliklerinin Şekil 9' da gösterilen Neps $(+\% 200 / \mathrm{km})$ oranlarında, Ne 20/1 numarada üretilmiş ipliklerin Neps $(+\% 200 / \mathrm{km})$ oranlarına benzer bir şekilde değişiklikler izlenmektedir. Ön manşonun sahip olduğu çap değeri arttıkça, Neps $(+\% 200 / \mathrm{km})$ değerleri düşüş göstermiştir. Arka manşonda ise bunun tam tersi bir durum gözlenmektedir. Diğer bir ifadeyle arka manşon çapı azaldıkça, Neps (+\%200/km) değerinde de azalma olmuştur. 


\subsubsection{Düzgünsüzlük analiz sonuçları}

Manşon çap kombinasyonlarının Ne 40/1 karde ring ipliği düzgünsüzlük değeri üzerinde bir etkisinin olup olmadığını araştırmak amacıyla Tek Yönlü ANOVA analizi yapılmıştır. Analiz sonuçları Tablo 6'da verilmiştir.

Tablo 6. Manşon Çap Kombinasyonlarına Göre Ne 40/1 Karde Ring İplik Düzgünsüzlük Değeri ANOVA

\begin{tabular}{lllllll}
\multicolumn{9}{c}{ Analizi Sonuçlar1 } & & & \\
\hline CVm (\%) & & Kareler Toplamı & df & Kareler Ortalamas1 & F & p. \\
& Gruplararas1 & 3,322 & 3 & 1,107 & 4,073 & $0,014^{*}$ \\
& Grupiçi & 9,788 & 36 & 0,272 & & \\
& Toplam & 13,110 & 39 & & & \\
\hline
\end{tabular}

*: 0.05 seviyesinde istatistiksel açıdan anlamlı bir fark vardır.

Ring iplik eğirme makinasında üretilen $\mathrm{Ne}$ 40/1 numara karde ipliklerin manşon çap kombinasyonlarına göre CVm (\%) ortalama değerleri arasında anlamlı fark bulunmaktadır ( $\mathrm{p}<.05)$.

$\mathrm{Bu}$ anlamlı farkların hangi manşon çapı grupları arasında olduğunu belirlemek için LSD post hoc analizine başvurulmuş olup elde edilen sonuçlar Tablo 7'de verilmiştir.

Tablo 7. Ne 40/1 Karde Ring İplik Düzgünsüzlük LSD Sonuçları

\begin{tabular}{llllll}
\hline & Manşon Çap Grupları & & Ortalama Fark & Std. Hata & $\mathrm{p}$ \\
\hline CVm (\%) & K-1 & K-2 & $-0,13500$ & 0,23319 & 0,566 \\
\cline { 3 - 6 } & & K-3 &,$- 71900^{*}$ & 0,23319 & $0,004^{*}$ \\
\cline { 2 - 6 } & K-4 &,$- 51600^{*}$ & 0,23319 & $0,033^{*}$ \\
\cline { 2 - 6 } & K-2 & K-3 &,$- 58400^{*}$ & 0,23319 & $0,017^{*}$ \\
\cline { 2 - 6 } & K-4 & $-0,38100$ & 0,23319 & 0,111 \\
\cline { 2 - 6 } & K-3 & K-4 & 0,20300 & 0,23319 & 0,390 \\
\hline
\end{tabular}

*: 0.05 seviyesinde istatistiksel açıdan anlamlı bir fark vardır.

Manşon çap kombinasyonlarında, CVm (\%) değerleri arasındaki anlamlı farklar K-1 manşon çapı grubu ile K-3 ve K-4 manşon çapı grupları arasında, ayrıca K-2 ile K-3 manşon çapı grupları arasında görülmüştür. LSD post hoc analizi sonuçlarına göre en düşük CVm (\%) ortalama değerine K-1 manşon çaplarında rastlanırken (\%16,09), en yüksek CVm (\%) değeri K-3 manşon grubunda $(\% 16,81)$ ortaya çıkmıştır. 


\subsubsection{IPI analiz sonuçları}

Manşon çap kombinasyonlarının Ne 40/1 karde ring ipliği düzgünsüzlük değeri üzerinde bir etkisinin olup olmadığını araştırmak amacıyla Tek Yönlü ANOVA analizi yapılmıştır. Analiz sonuçları Tablo 8'de verilmiştir.

Tablo 8. Manşon Çap Kombinasyonlarına Göre Ne 40/1 Karde Ring İplik Düzgünsüzlük Değeri ANOVA

\begin{tabular}{|c|c|c|c|c|c|c|}
\hline & & Analizi Son & & & & \\
\hline & & Kareler Toplamı & $\mathrm{df}$ & Kareler Ortalamas 1 & $\mathrm{~F}$ & p. \\
\hline İnce Yer (- & Gruplararas1 & 2981029,419 & 3 & 993676,473 & 1,522 & 0,225 \\
\hline$\% 40 / \mathrm{km})$ & Grupiçi & 23496973,275 & 36 & 652693,702 & & \\
\hline & Toplam & 26478002,694 & 39 & & & \\
\hline Kalın Yer & Gruplararas1 & 433861,700 & 3 & 144620,567 & 2,491 & 0,076 \\
\hline$(+\% 35 / \mathrm{km})$ & Grupiçi & 2089717,400 & 36 & 58047,706 & & \\
\hline & Toplam & 2523579,100 & 39 & & & \\
\hline Neps $(+\% 200 / \mathrm{km})$ & Gruplararas1 & 17623,125 & 3 & 5874,375 & 0,810 & 0,497 \\
\hline & Grupiçi & 261038,750 & 36 & 7251,076 & & \\
\hline & Toplam & 278661,875 & 39 & & & \\
\hline
\end{tabular}

*: 0.05 seviyesinde istatistiksel açıdan anlamlı bir fark vardır.

Ring iplik eğirme makinasında üretilen Ne 40/1 numara karde ipliklerin manşon çap kombinasyonlarına göre IPI ortalama değerleri arasında herhangi bir anlamlı fark bulunmamaktadır (p>.05). Dolayısıyla, Anova analizinde bulunan anlamlı farkların hangi manşon çap kombinasyonları arasında olduğunu belirmemizi sağlayan LSD post hoc analizi yapılmamıştır.

\section{Tartışma ve Sonuç}

Ne 20/1 ve Ne 40/1 numaralarında ve dört farklı (30 mm ve $28 \mathrm{~mm}$ ) ön ve arka manşon çap kombinasyonlarında \%100 pamuk hammaddesinden üretilen karde ring ipliklerin düzgünsüzlük ve IPI değerlerini incelemeyi amaçlayan bu çalışmanın sonucunda ön manşon çapının nihai ipliğin düzgünsüzlük ve IPI değerlerinde, özellikle de CVm (\%), İnce Yer (-\%40/km) ve Kalın Yer (+\%35/km) değerlerinde, anlamlı bir etkisi olduğu bulunmuştur. 


\subsection{CVm (\%)}

Çalışma kapsamında yapılan ölçümler sonucu, üretilen her iki numaradaki (Ne 20/1 ve $\mathrm{Ne}$ 40/1) iplik numuneleri için, ön manşon çapının yüksek olduğu kombinasyonlarda (K-1, K-2), arka manşon çap değerinin azalması CVm (\%) değerinin artmasına yol açmıştır. Artış oranı Ne 20/1 için \% 1,20 olurken, Ne 40/1 için bu oran \% 0,8 olarak tespit edilmiştir. Arka manşon çapının büyük olduğu kombinasyonlarda ise (K-1, K-3) ön manşon çapının azalması yine $\mathrm{CVm}(\%)$ değerinin artmasına yol açmıştır. Artış oranı Ne 20/1 için \% 1,99 olurken, Ne 40/1 için bu oran \% 4,47 olarak gerçekleşmiştir. Bu sonuçlar göz önüne alındığında, ön manşon çap değerinin azalması, arka manşon çap değerinin azalmasına oranla $\operatorname{CVm}(\%)$ değeri üzerinde daha fazla bir negatif etkiye sahip olduğu bulunmuştur. Bu sonuç, alanda manşon çapı üzerine yapılmış diğer çalışmaları da destekler niteliktedir (Ghane ve ark., 2008; Xu, 2005).

\section{2. İnce Yer $(-\% 40 / \mathrm{km})$}

Ne 20/1 ve Ne 40/1 karde iplik numuneleri için ön manşon çapının yüksek olduğu kombinasyonlarda (K-1, K-2), arka manşon çap değerinin azalması Ne 20/1 için \% 39,5 oranında, Ne 40/1 için ise \% 12,8 oranında bir İnce Yer (-\%40/km) artışına neden olmuştur. Arka manşon çap değerinin büyük olduğu kombinasyonlarda (K-1, K-3) ise ön manşon çap değerinin azalması Ne 20/1 için \% 51,1, Ne 40/1 için ise \% 46,1 oranında bir İnce Yer (-\%40/km) artışına sebep olduğu bulunmuştur. Manşon çapının konu edildiği alandaki diğer çalışmaları (Ghane ve ark., 2008) destekler nitelikte bulunan sonuçların ışı̆̆ında, ön manşon çap değerinin azalması, arka manşon çap değerinin azalmasına oranla İnce Yer $(-\% 40 / \mathrm{km})$ değeri üzerinde çok daha yüksek bir negatif etkiye sahip olduğu bulunmuştur.

\subsection{Kalın Yer $(+\% 35 / \mathrm{km})$}

Ön manşon çapının yüksek olduğu kombinasyonlarda (K-1, K-2), Ne 20/1 ve Ne 40/1 karde iplik numuneleri için arka manşon çap değerinin azalması, Ne 20/1 için \% 5,7 oranında, Ne 40/1 için ise \% 0,3 oranında bir Kalın Yer $(+\% 35 / \mathrm{km})$ artışına neden olmuştur. Arka manşon çap değerinin büyük olduğu kombinasyonlarda (K-1, K-3) ise ön manşon çap değerinin azalması Ne 20/1 için \% 20, Ne 40/1 için ise \% 17,2 oranında Kalın Yer (+\%35/km) artışına sebep olduğu 
bulunmuştur. Buna göre, ön manşon çap değerinin azalması, arka manşon çap değerinin azalmasına oranla, İnce Yer $(-\% 40 / \mathrm{km})$ değerinde olduğu gibi Kalın Yer $(+\% 35 / \mathrm{km})$ değeri üzerinde de, çok daha fazla bir oranda negatif etki ettiği bulunmuştur.

\subsection{Neps $(+\% 200 / \mathrm{km})$}

Mevcut çalışmanın sonucunda, her iki iplik numarasında ( $\mathrm{Ne}$ 20/1 ve $\mathrm{Ne}$ 40/1) üretilmiş ipliklerin arka manşon çaplarının büyüklüğüne göre Neps $(+\% 200 / \mathrm{km})$ değerlerinde farklılıklar bulunmaktadır. İstatistiki açından anlamlı bir fark bulunamasa da, arka manşon çap değerinin büyük olduğu çap kombinasyonlarında (K-1 ve K-3), ön manşon çap değerinin azalması Neps (+\%200/km) değerlerinde Ne 20/1 için \% 7,2, Ne 40/1 için ise \% 5,9 oranında bir artışa neden olduğu bulunmuştur. Ön manşon çapının yüksek olduğu çap kombinasyonlarında (K-1 ve K-2), arka manşon çapının azalmasıyla Neps (+\%200/km) değerlerinde Ne 20/1 için \% -6,6, Ne 40/1 için ise \% -6,7 oranında bir azalma yaşandığ tespit edilmiştir. Her ne kadar bu durum beklenenin tam tersi doğrultuda gerçekleşmiş olsa da, periyodik olarak planlanan manşon taşlama işleminin, iplik kalitesini ve makine verimliliğini artırmaya yardımcı olduğu da bilinmektedir (Canoğlu, 2013). Dolayısıyla bu çalışma için üretilmiş olan karde ring ipliklerin, deneyin yapılmış olduğu üretim hattındaki manşonların düzenli olarak taşlanmasından ve manşonlar üzerinde ciddi ve derin hasarın olmamasından ötürü böyle bir sonuca ulaşılmış olabileceği belirtilebilir.

Sonuç olarak, kaliteli ring ipliği üretiminde manşon çapının önemli bir etkisi olduğu, dolayısıyla özellikle de ön manşonlarda daha büyük çapta manşonların tercih edilmesinin iplik kalitesi açısından daha iyi sonuçlar doğuracağı ortaya çıkmaktadır. Benzer şekilde, manşonların bakım ve taşlama işlemlerinin de bu süreç için önem arz ettiği bulunmuştur. Bu doğrultuda, ring ipliği üreten işletmelerin yüksek verim elde edebilmeleri adına manşon çapını ve periyodik bakımın önemini göz önünde bulundurmaları önerilir.

\section{Kaynaklar}

Akbar, A. R., Zeshan, M., Neaz, M., Cai, Y., and Lin, L. (2017). Effect of Ring Machine Front Roller Rubber Cot Hardness on Properties of Coarser Yarn. In MATEC Web of Conferences (Vol. 130, p. 02003). EDP Sciences.

Bagwan, A. S., Policepatil, R., and Pawar, S. (2016). Optimizing effects of cots shore hardness on cotton yarn properties at ring frame. J Text Sci Eng, 6(1), 238. 
Bedez Ute, T. (2012). Sirospun Pamuk Ípliklerinde Íplik Özellikleri İle Lif Özellikleri Arasındaki İlişkinin Fonksiyonel Olarak Tahminlenmesi Üzerine Bir Araştırma. Doktora Tezi, Ege Üniversitesi, Fen Bilimleri Enstitüsü, İzmir.

Canoğlu, S. (2013). Effects of Ring Machine Apron and Cot Components On Yarn Quality. Journal of Textile \& Apparel/Tekstil ve Konfeksiyon, 23(3), 213-219.

Chaudhary, V., Joshi, M., and Shivankar, V. S. (2018). Effect of cot hardness on quality of ring spun yarn. Technical Textiles, 1-2. Retrieved from https://www.researchgate.net/profile/Vijay_Chaudhari3/publication/328496938_MI_4_Chaudhary/lin ks/5bd1892892851cabf2664f1e/MI-4-Chaudhary.pdf

Chakrabortty, A., Hasan, M. Z., Ghosh, J., and Redwanul, M. (2020). Impact of Front and Back Roller Shore Hardness on The Quality of Cotton Carded Yarn in Ring Spinning Frame. Trends Textile Eng. Fashion Technol, 5(5), 682-686.

Commercial Standardization of Instrument Testing of Cotton (2020). USTER ${ }^{\circledR H V I}$ Test results. Retrieved from:

https://csitc.org/sitecontent/RTCEA/internal_ea/02_RTC_Content/022_Training/0222_Traini ng_documents/02225_USTER/Application\%20Manual/0222511_TestResults.pdf

Erdal, Ö. Z. (2006). Makinalı pamuk hasadının pamuk lif kalitesi üzerindeki etkilerinin çiftçi koşullarında belirlenmesi. Selçuk-Teknik Dergisi, 2(2).

Ferede, E. (2017). Effect of spinning top front roller rubber cot shore hardness on yarn quality.

Foulk, J. A., and Mcalister III, D. D. (2002). Single cotton fiber properties of low, ideal, and high micronaire values. Textile Research Journal, 72(10), 885-891.

Ghane, M., Semnani, D., Saghafi, R., and Beigzadeh, H. (2008). Optimization of top roller diameter of ring machine to enhance yarn evenness by using artificial intelligence. Indian Journal of Fibre and Textile Research, 33, 365-370.

Kane, C. D., and Ghalsasi, S. G. (1992). Studies on ring frame drafting: Part I. Indian Textile Journal, 102, 78-78.

Katı, E. (2004). Farklı İplik Düzgünsüzlüğü Test Cihazlarından Elde Edilen Sonuçların Karşılaştırılması. Doktora Tezi, Süleyman Demirel Üniversitesi, Fen Bilimleri Enstitüsü, Isparta.

Khurshid, F., Aslam, S., Ali, U., Abbas, A., Hamdani, T. A., \& Hussain, F. (2018). Optimization of break draft, pin spacer and rubber cots hardness to enhance the quality of ring spun yarn using factorial design. Journal of Engineered Fibers and Fabrics, 13(2), 155892501801300209.

Lawrence, C. A. (2003). Fundamentals of spun yarn technology. Crc Press.

Majumdar, P. K., and Majumdar, A. (2004). Predicting the breaking elongation of ring spun cotton yarns using mathematical, statistical, and artificial neural network models. Textile Research Journal, 74(7), 652-655.

Sujai, B., and Sivakumar, M. (2015) Effect of Spinning Rubber Cot Shore Hardness on Yarn Mass Uniformity and Imperfection Levels-Part.

Şahin, M. Ö. (2015). Pamukta (Gossypium Hirsutum L.) Balya Depolama Sürelerinin Lif Kalitesi Üzerine Etkisi. Yüksek Lisan Tezi, Adnan Menderes Üniversitesi, Fen Bilimleri Enstitüsü, Aydın.

Thilagavathi, G., and Karthik, T. (Eds.). (2016). Process control and yarn quality in spinning. CRC Press.

Toprakçı, O. (2008). Ring Íplikçiliğinde Lif Özelliklerinden Pamuk İpliği Özelliklerinin Tahminlenmesinin Araştırılması. Yüksek Lisans Tezi, Pamukkale Üniversitesi, Fen Bilimleri Enstitüsü, Denizli.

Xu, Z. G. L. (2005). Spinning Test of Big Diameter Spinning Top Roller [J]. Cotton Textile Technology, 9. 